\title{
Novel point mutations in $\beta$-tubulin gene for carbendazim resistance maintaining nematode pathogenicity of Paecilomyces lilacinus
}

\author{
Fan Yang • Hazem Abdelnabby • Yannong Xiao
}

Accepted: 27 April 2015 / Published online: 4 May 2015

(C) Koninklijke Nederlandse Planteziektenkundige Vereniging 2015

\begin{abstract}
The application of fungicides is so critical, especially in greenhouses, to avoid fungal infections. Carbendazim, an inhibitor of tubulin biosynthesis, is the most widely known broad-spectrum benzimidazole fungicide. The application of carbendazim affects other beneficial fungi as well. Paecilomyces lilacinus 36-1 (Pl36-1) is a beneficial fungus used for biological control, and the most effective biocontrol agents of nematode eggs. The Pl36-1 is sensitive to carbendazim $(0.3 \mu \mathrm{g} / \mathrm{ml})$. There is a general consensus that the mechanisms of resistance to carbendazim in the $\beta$-tubulin gene have been analyzed in detail. However, no studies were conducted on P. lilacinus strains. In the present study, two carbendazim-resistant mutants of Pl36-1, P50 and P100, were obtained from UV exposure and tested. The $\beta$-tubulin gene fragments were cloned and sequenced in the three strains, Pl36-1, P50 and P100. The resistance to carbendazim was developed when amino acid substitutions occurred at $\beta$-tubulin gene positions of S145A, T185A and F200Y. The $\beta$-tubulin gene was overexpressed in Pl36-1 strains. The $\beta$-tubulin
\end{abstract}

Electronic supplementary material The online version of this article (doi:10.1007/s10658-015-0665-0) contains supplementary material, which is available to authorized users.

F. Yang $\cdot$ H. Abdelnabby $\cdot$ Y. Xiao $(\bowtie)$

Key Laboratory of Plant Pathology of Hubei Province, Huazhong Agricultural University, Wuhan, Hubei 430070, China

e-mail: xiaoyannong@mail.hzau.edu.cn

H. Abdelnabby

Department of Plant Protection, Faculty of Agriculture, Benha University, Benha, Qaliubia 13736, Egypt expression level of the overexpressed mutant (PL3), quantified by qRT-PCR, was increased 4-folds over its normal level in Pl36-1. In vitro, the PL3 was resistant to carbendazim with maintaining growth, sporulation and pathogenicity rates. Three-year field trial demonstrated that P100 and PL3 strains exhibited carbendazim resistance combined with high nematode reduction and yield improvement.

Keywords $\beta$-tubulin Paecilomyces lilacinus . Carbendazim resistance - Amino acid substitutions . Meloidogyne incognita

\section{Introduction}

Nematodes are destructive plant pathogens responsible for yield losses in numerous economic crops. A huge amount of damage is caused by endo-parasitic sedentary nematodes which generate particular feeding sites in plant roots. The most common of these pathogens, root-knot nematodes "RKN" (family: Meloidogynidae) are the major plant parasitic species with economic value (de Almeida Engler et al. 2005). Root-knot nematodes (Meloidogyne spp.) are obligatory and substantial parasites of many economic crops (Javed et al. 2006). Controlling root-knot nematodes is of major economic importance to the agricultural industry of China (Huang et al. 2014). Meloidogyne arenaria, M. incognita and M. javanica are the main species responsible for yield losses in vegetable cropping areas (Sikora and Fernandez 2005). These nematodes belonging to this 
genus play a crucial role for their important phytosanitary implications often pave the way to emergent, opportunistic or well-known pathogenic fungi on cultivated crops (Bertrand et al. 2000; Dimartino et al. 2011; Gallo et al. 2011; Starr et al. 1989; Vitale et al. 2011, 2014). Recently, the most efficient chemical control products (e.g., methyl bromide) have been restricted due to their animal and human toxicity. Research on biological control agents (BCAs) against root-knot nematodes which have no deep impact on the environment is becoming increasinglyrequested (Yang et al. 2011; Abdelnabby et al. 2011). Many fungi and their metabolites are known to have nematicidal activity against a wide range of plant-parasitic nematodes including RKNs (Kiewnick and Sikora 2006; Hallman et al. 2009). In the last two decades, many efforts yielded an adequate number of bioformulations containing several BCAs. Among the well-accepted commercial products is the fungus Paecilomyces lilacinus (Lamovsek et al. 2013).

Paecilomyces lilacinus (Thom) Samson, a soilinhabiting and egg-parasitic fungus, is one of the most effective opportunistic parasites of nematode eggs (Khan et al. 2006). There are promising results with the use of P. lilacinus 251 (PL251) as a biological control agent against various plant-parasitic nematodes (Anastasiadis et al. 2008; Yang et al. 2011; Crow 2013). PL251 strain reduces infestation with $M$. incognita by nearly $66 \%$ (Kiewnick and Sikora 2006). Commercial products of $P$. lilacinus are marketed in Europe, Central America and North Africa (Wilson and Jackson 2013). According to the common agricultural practices, P. lilacinus applications are combined with fungicide treatments to prevent secondary and associate infections caused by soilborne fungi (Anastasiadis et al. 2008). Paecilomyces lilacinus 36-1 was isolated from M. incognita in our laboratory and showed effective control of root-knot nematode as well as soybean cyst nematode diseases. The isolated P. lilacinus 36-1 was sensitive to the fungicide carbendazim applied at a rate of $0.3 \mu \mathrm{g} / \mathrm{ml}$. Its efficacy on nematode control has been reduced when carbendazim was applied to control fungal diseases under greenhouse and field conditions.

Resistance to carbendazim fungicide has been detected with several species of fungi in laboratory and field studies (Davidse and Ishii 1995; Brent and Hollomon 2007). It is well known that the basic resistance mechanism of fungal species to fungicides is due to a modification at the target-site of fungicidal action (Brent and
Hollomon 1998). The interrelationships of carbendazim resistance with point mutations of the $\beta$-tubulin gene have been analyzed in details (Verhey and Gaetig 2007; Hammond et al. 2008; Cheng et al. 2009). Many studies have shown that the mechanism of action for carbendazim fungicides is binding to $\beta$-tubulin and preventing $\alpha$-tubulin assembly (Fujimura et al. 1992; Cools et al. 2011; Cools and Fraaije 2012). High and long persistence of resistance is characterized in the field after interrupted applications of the carbendazim fungicide due to $\beta$-tubulin amino acid substitutions E198A, E198V, E198K and F200Y (Georgopoulos and Skylakakis 1986; Yarden and Katan 1993; Leroux et al. 2002; Ma and Michailides 2005). Polymerase chain reaction (PCR) diagnostic assays can detect the E198A resistance mutations in Botrytis cinerea isolates (Luck and Gillings 1995; Banno et al. 2008). However, the molecular mechanisms of carbendazim-resistance in $P$. lilacinus are poorly detected and understood. Thus, the aim of this paper was focused on analysis of the carbendazim target sites of the $\beta$-tubulin gene from resistant transformants to improve carbendazimresistance with maintaining nematodes virulence of P. lilacinus.

\section{Materials and methods}

Strains and culture conditions

A wild strain of $P$. lilacinus 36-1 (Pl36-1), susceptible to $0.3 \mu \mathrm{g} / \mathrm{ml}$ of carbendazim, was isolated from eggs of M. incognita in our laboratory. The strain was cultured on potato dextrose agar (PDA) medium at $28{ }^{\circ} \mathrm{C}$ for 7 days. For long-term storage, it was maintained in glass tubes on PDA medium at $4{ }^{\circ} \mathrm{C}$ in darkness with one transfer every 6 months. Sclerotinia sclerotiorum A (SA) strain stored in our laboratory was cultured on PDA medium at $22{ }^{\circ} \mathrm{C}$ for 4 days.

Development of UV-induced carbendazim-resistant mutants of $P$. lilacinus 36-1

The UV-induced carbendazim-resistant mutants were developed according to the procedure of Tanaka et al. (1988). Ten ml aliquots of Paecilomyces lilacinus 36-1 conidial suspension $\left(1 \times 10^{4}\right.$ conidia/ml $)$ containing Tween $20(0.02 \% v / v)$ was poured into a petri plate and exposed to UV irradiation (254 nm Phillips TUV 
$25 \mathrm{~W} / \mathrm{h}$ ) at a distance of $15 \mathrm{~cm}$ for $0.5,1,1.5$ and $2 \mathrm{~min}$. The conidia were incubated in the dark for $8 \mathrm{~h}$ to prevent photo-reactivation. Aliquots of $100 \mu \mathrm{l}$ of treated conidia $\left(1 \times 10^{4}\right.$ conidia $\left./ \mathrm{ml}\right)$ with mutagens were plated separately on PDA amended with carbendazim at the rate of $1 \mu \mathrm{g} / \mathrm{ml}$. The petri plates were incubated at $28 \mathrm{C}$ for 3 days. The growing mutant strains were transferred to PDA medium containing carbendazim solution at concentrations of $1,5,10,50,60,100$ and $150 \mu \mathrm{g} / \mathrm{ml}$. Survival rates were determined from the ratio of colonies which grew on fungicide amended media and number of conidia inoculated.

Stability test for fungicide resistance of tested mutants

Carbendazim resistant mutants were subcultured on fungicide-free PDA medium for 10 generations. Consequently, the mutants were transferred to the respective fungicide " $1 \mu \mathrm{g} / \mathrm{ml}$ " amended PDA medium. Stability rate was determined from the ratio of survived colonies which grew on the fungicide amended medium and number of colonies inoculated. The carbendazim resistant mutant strains obtained by UV-irradiation were designated.

Extraction of DNA and RNA, and cDNA synthesis

P. lilacinus cultures were grown on PDA at $28{ }^{\circ} \mathrm{C}$ for 7 days. Mycelia were peeled and ground under liquid nitrogen. Genomic DNA was extracted using $2 \%$ CTAB buffer. Total RNA was isolated using TRIzol reagent (Invitrogen). First-strand cDNA was synthesized from total RNA. Genomic DNA was removed using TransScript TM II RT/RI Enzyme Mix (Transgen).

Sequence analysis of $\beta$-tubulin gene

The specific degenerate primers bctubF (5'-ACAACC GCCAACATGC GTGAGATTGTGA-3') and bctubR (5'-CTCCATCTCGTCCATTCCTTTCGCCTG -3') were designed based on the cited sequences of N. haematococca mpVI 77-13-4, A. fumigatus Af293, T. stipitatus ATCC10500, A. niger CBS531.88 and G. zeae PH-1, in the GenBank database (http://www. ncbi.nlm.nih.gov/nuccore/). These primers were used to amplify full-length sequences of gDNA in $50 \mu$ of PCR reaction system containing $5 \mu$ of $10 \times$ LA PCR BufferII $\left(\mathrm{Mg}^{2+}\right.$ Plus) (TaKaRa), $8 \mu \mathrm{l}$ of $2.5 \mathrm{mM}$ deoxyribonucleoside triphosphate (dNTPs) (TaKaRa),
$1 \mu \mathrm{l}$ of each primer $(20 \mu \mathrm{M}$ of each bctubF and bctubR), $0.5 \mu$ l of $5 \mathrm{U} / \mu \mathrm{l}$ LATaq (TaKaRa) and 32 . $5 \mu \mathrm{l}$ of sterilized distilled water $\left(\mathrm{ddH}_{2} \mathrm{O}\right)$. Genomic DNA $(2 \mu \mathrm{l})$ from Pl36-1 and P100 were applied as templates. The PCR cycling conditions were $94{ }^{\circ} \mathrm{C}$ for 5 min followed by 35 cycles of $94{ }^{\circ} \mathrm{C}$ for $40 \mathrm{~s}, 63.5^{\circ} \mathrm{C}$ for $1 \mathrm{~min}$, and $72{ }^{\circ} \mathrm{C}$ for $2 \mathrm{~min}$; then finally $10 \mathrm{~min}$ extension at $72{ }^{\circ} \mathrm{C}$. The PCR products of the expected size were ligated to pMD18-T vector (TaKaRa) and at least 10 independent clones from each strain were sequenced in both directions and analyzed. Sequence data were analyzed using DNAStar software (DNAstar, Madison, USA).

Phylogenetic characterization

The sequences of the PCR products were compared to known $\beta$-tubulin gene sequences in the GenBank database by multiple sequence alignment using ClustalX 1.83 and GeneDoc. Phylogenetic tree construction was performed using the neighbor-joining method with MEGA 5.1.3.

3D homology model of developed $\beta$-tubulin

The change of $\beta$-tubulin 3-D appearance may affect fungicide binding ability leading to carbendazimresistance of $P$. lilacinus mutants. Three-dimensional and surface structures of the $\beta$-tubulin gene protein were successfully predicted and constructed using Pymol software (http://www.pymol.org/). The constructed surface structure of P100 mutant was compared with that of wild strain (Pl36-1), to determine the amino acid substitutions and their effect on the surface structure appearance.

Expression vector construction

For further studies, six new vectors p1, p2, p3, p4, p5 and $\mathrm{p} 6$ were reconstructed based on $\mathrm{pEGAD}-\mathrm{CBX}$ vector containing carboxin resistance gene CBX (Fig. 1). In the six applied vectors, the $\beta$-tubulin gene would substitute bar gene as a selectable marker. The amino acid residues, S145A and F200Y, of $\beta$-tubulin gene were substituted in $\mathrm{p} 1$ vector, T185A and F200Y in $\mathrm{p} 2$ vector, S145A, T185A and F200Y in p3 vector, S145A in p4 vector, while $\mathrm{T} 185 \mathrm{~A}$ in $\mathrm{p} 5$ vector, and $\mathrm{S} 145 \mathrm{~A}$ and $\mathrm{T} 185 \mathrm{~A}$ in $\mathrm{p} 6$ vector. The applied vectors were 


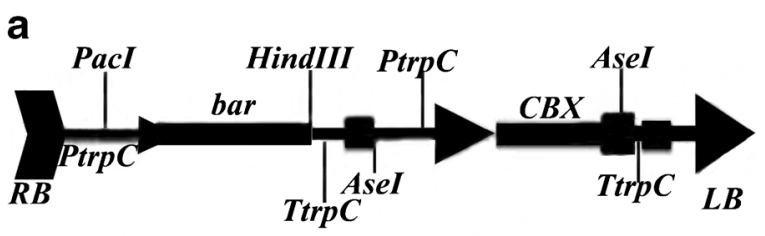

b

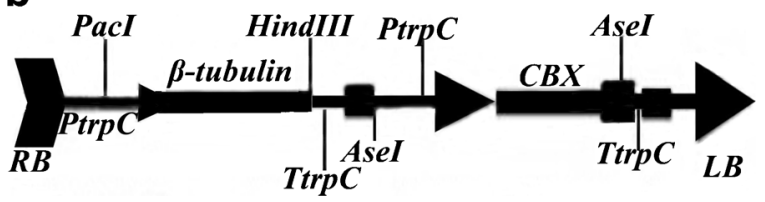

Fig. 1 Construction of the expression vectors. a T-DNA of the binary vector $p E G A D-C B X$ containing two selectable markers coding for resistance genes ( $b a r$ and $C B X$ ). b T-DNA of the binary vectors $\mathrm{P} 1, \mathrm{P} 2, \mathrm{P} 3, \mathrm{P} 4, \mathrm{P} 5$ and $\mathrm{P} 6$ containing two selectable markers coding for resistance genes $(\beta$-tubulin and $C B X)$. The $\beta$ tubulin gene had two amino acid residues S145A and F200Y were substituted in $\mathrm{p} 1$ vector, T185A and F200Y were substituted in $\mathrm{p} 2$ vector, and S145A, T185A and F200Y were substituted in $\mathrm{p} 3$ vector, S145A in p4 vector, while T185A in p5 vector, and $\mathrm{S} 145 \mathrm{~A}$ and $\mathrm{T} 185 \mathrm{~A}$ in $\mathrm{p} 6$ vector

respectively transferred to $P$. lilacinus and S. sclerotiorum A strains using agrobacterium-mediated (ATMT).

Expression level of $\beta$-tubulin

The applied primers for quantitative RT-PCR (qRT$\mathrm{PCR})$ were bctubF/R for $\beta$-tubulin gene and $\operatorname{actF} / \mathrm{R}$ (actF:5' - ATCCACATCACCACTTGCAA; actR:5' - TGCTCGGAGATCGACATTTG) for the actin gene. All data were normalized to actin gene expression. Relative changes in gene expression levels were analyzed. qRT-PCR data from three biological replicates were used to calculate the mean and standard deviation (SD) in the expression level of each gene.

\section{Virulence test of $P$. lilacinus}

\section{Laboratory tests}

The pathogenicity of $P$. lilacinus $36-1$ and the transformant strains were examined against $M$. incognita by calculating the rate of egg parasitism and larval mortality. A total of $0.5 \mathrm{~mL}$ of conidial suspension $\left(10^{6} \mathrm{CFU} / \mathrm{ml}\right)$ was mixed with $0.5 \mathrm{ml}$ eggs or juvenile suspension of $M$. incognita (100 eggs/ $0.5 \mathrm{ml}$ or 100 juveniles/ $0.5 \mathrm{ml}$ ). The control was prepared by mixing $0.5 \mathrm{ml}$ of $\mathrm{H}_{2} \mathrm{O}$ with $0.5 \mathrm{ml}$ of eggs or juveniles suspension. All treatments were incubated at $28{ }^{\circ} \mathrm{C}$. Three replications were applied for each treatment. The egg parasitism ratio and nematode mortality rates were recorded for each treatment at 48-h time intervals. The experiment lasted 6 days.

\section{Field experiments}

Three P. lilacinus strains P36-1, P100, and PL3 were selected for further tests under field conditions. The field experiment was conducted in a controlled greenhouse with a serious nematode infection, (Huazhong Agricultural University, Wuhan, China). The experiments were conducted at three successive seasons: December 2012 to February 2013 on cucumber, November 2013 to January 2014 on tomatoes and March 2014 to June 2014 on cucumber. During these periods, the average of temperature was $25.8 \pm 2{ }^{\circ} \mathrm{C}$, while relative humidity recorded $56 \pm 3 \%$. The experiment adopted a randomized complete block design with five replicate plots $(5 \times$ $2 \mathrm{~m})$ per treatment. Plots within blocks were separated by $1 \mathrm{~m}$-wide buffers and blocks were separated by $2 \mathrm{~m}$ wide buffers. After 4 weeks of crop growth, 21 spore suspension $(107 \mathrm{CFU} / \mathrm{ml})$ of each $P$. lilacinus treatment was uniformly sprayed at each plot. One week later, 21 of carbendazim $(100 \mu \mathrm{g} / \mathrm{m})$ was sprayed on each fungal treated plot. The plot free of spores suspension and carbendazim is a negative control (CK-), while the plot which received carbendazim and free of fungal treatment is control (CK). At the end of growth season, soil and plant roots were collected. Nematodes were extracted from sub-samples of $100 \mathrm{~g}$ soil with a modified Baerman Funnel method as described by Hooper (1984). Additionally, root gall index (mean root samples of 20) was determined on a scale of 0 to 5 based on the percentage of the root system with galls (Hussey and Janssen 2002), where $0=$ no galling; $1=$ trace infection with a few small galls; $2=\leq 25 \%$ roots galled; $3=26$ to $50 \%$; $4=51$ to $75 \%$; and $5=>75 \%$ roots galled.

\section{Statistical analysis}

Statistical analysis was carried out using SPSS 12.0.1. The data were expressed as mean $\pm \mathrm{SD}$. Groups were compared by Duncan's Multiple Range Test to identify 
significance of difference between groups. $\mathrm{P}$ value $<$ 0.05 was considered statistically significant.

\section{Results}

Induction of $\mathrm{UV}$ mutation of $P$. lilacinus 36-1

UV method has been applied to produce a number of laboratory mutants. Seven hundreds of mutants were produced and screened on PDA amended with carbendazim at concentration of $1 \mu \mathrm{g} / \mathrm{ml}$. Resistant colonies were picked up and stored in test tube slants amended with $1 \mu \mathrm{g} / \mathrm{ml}$ carbendazim. Data reported in Tables 1 and 2 show the obtained colonies by UV irradiation and the survival rates with different concentration levels of carbendazim. The tested strains which retained resistant after 10 generations were considered while selecting the suitable mutants for further analysis. The P100 mutant was chosen for further studies according to its high resistance and stability. The $\beta$-tubulin gene of P100 was compared to P50 and the sensitive strain $P l 36-1$.

Sequencing $\beta$-tubulin gene and phylogenetic characterization

Nucleotide sequences of Pl36-1, P50 and P100 were obtained by PCR amplification and sequencing. The full length of the $\beta$-tubulin gene of $P$. lilacinus 36-1was $1624 \mathrm{bp}$, cDNA was $1206 \mathrm{bp}$, encoding 402 amino acids. The full-

Table 1 P136-1 mutations induced by ultraviolet light

\begin{tabular}{llll}
\hline $\begin{array}{l}\text { Exposure time } \\
(\mathrm{min})\end{array}$ & Mutation & $\begin{array}{l}\% \text { of } \\
\text { survival }\end{array}$ \\
\cline { 2 - 3 } & $\begin{array}{l}\text { No. of } \\
\text { mutants }\end{array}$ & $\begin{array}{l}\text { No. of } \\
\text { survived colonies }\end{array}$ \\
\hline 0.5 & 648 & 149 & 23 \\
1 & 593 & 190 & 32 \\
1.5 & 413 & 331 & 80 \\
2 & 647 & 97 & 15 \\
\hline
\end{tabular}

Spore concentration: $1 \times 10^{4}$, Incubation period: 3 days, No. of colonies survived and $\%$ of survival were calculated according to stability test experiment
Table 2 Survival rates of mutant strains under different concentrations of carbendazim

\begin{tabular}{lll}
\hline $\begin{array}{l}\text { Concentration of carbendazim } \\
(\mu \mathrm{g} / \mathrm{mL})\end{array}$ & $\begin{array}{l}\text { No. of survived } \\
\text { colonies }\end{array}$ & $\begin{array}{l}\text { \% of } \\
\text { survival }\end{array}$ \\
\hline 1 & 500 & 100 \\
5 & 492 & 98.4 \\
10 & 485 & 97 \\
50 & 473 & 94.6 \\
60 & 356 & 71.2 \\
100 & 320 & 64 \\
150 & 10 & 12.4 \\
\hline
\end{tabular}

Spore concentration: $1 \times 10^{4}$, Incubation period: 5 days

length sequence and cDNA of the $\beta$-tubulin gene of P100 were the same like $P l$ 36-1 (Fig. 2). Amino Acids Sequence Comparison of $\beta$ - tubulin gene with common plant pathogenic fungi using the blastp (http://blast.ncbi.nlm.nih.gov/Blast.cgi) indicated high homology at amino acid level ranging from 95.3 to $99.2 \%$ and containing five exons and four introns (Table 3).

The described bioassay data indicated modifications in the target-site responsible for resistance to carbendazim. The amino-acid positions of amplified $\beta$-tubulin gene varied within the range from codon 145 to 200 . Compared to the $\beta$-tubulin gene of Pl36-1, the amino acid residues of S145A, T185A and F200Y were replaced in P100 strain while only one amino acid residue "F200Y" was replaced with the strain of P50. On the other hand, both mutants did not produce any change in the amino acid residue of E198 (Fig. 2). Based on the obtained translation of nucleotide sequences, the amino-acids and their site replacements of the $\beta$-tubulin gene of the three strains are shown in Table 4. The phylogenetic trees showed a very close relationship ( $88 \%$ ) between P. lilacinus, Penicillium mameffei and Acremonium chrysogenumgi (Fig. 3).

Three-dimensional structures of the $\beta$-tubulin gene protein

Modeling of the 3-dimensional and surface structures of the $\beta$-tubulin gene protein were successfully predicted and constructed using Pymol software (http://www. pymol.org/). The surface structure of the codons 145 , 185 and 200 in P100 strain were changed compared to 


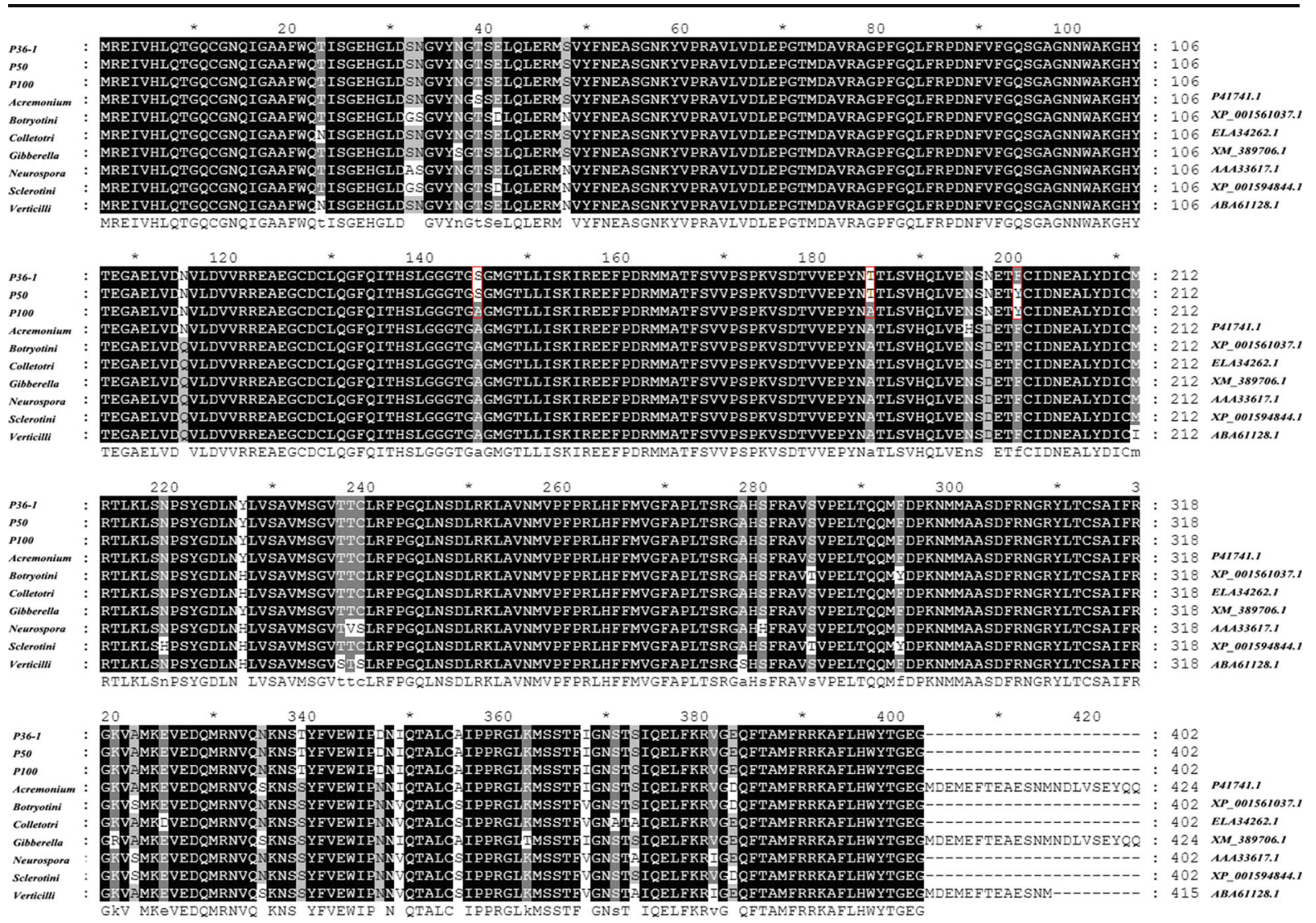

Fig. 2 Amino acid alignment of putative $\beta$-tubulin protein. Accession numbers: Acremonium, P41741.1; Gibberella, XM_389706.1; Verticillium, ABA61128.1; Sclerotinia, XP 001594844.1; Botryotinia, XP 001561037.1; Neurospora, AAA33617.1; Colletotrichum, ELA-34262.1. Comparing to the

the wild-strain Pl36-1. The amino acid residues Serine 145, Threonine 185 and Phenylalanine 200 were replaced with Alanine 145, Alanine 185 and Tyrosine $\beta$-tubulin gene of the wild strain Pl36-1, the mutants P50 and $\mathrm{P} 100$ have a tyrosine residue instead of phenylalanine at position 200, while the P100 mutant has two more points, S145A and T185A

200, respectively. According to amino acid substitutions in 3 sites, the 3D structure of P100 tubulin has been changed (Fig. 4).

Table 3 Comparison of the $\beta$-tubulin gene among different fungal species

\begin{tabular}{|c|c|c|c|}
\hline $\begin{array}{l}\text { Pathogenic } \\
\text { fungi }\end{array}$ & $\begin{array}{l}\text { Accession number of } \\
\text { nucleotide and amino } \\
\text { acid sequence }\end{array}$ & $\begin{array}{l}\text { The number } \\
\text { and size of introns }\end{array}$ & $\begin{array}{l}\text { Homology at amino } \\
\text { acid level \% }\end{array}$ \\
\hline Paecilomyces lilacinus $^{a}$ & KC415035 & $4(198,76,62,56 \mathrm{bp})$ & l \\
\hline Sclerotinia sclerotiorum & AY312374 & $4(182,8,48,53 \mathrm{bp})$ & 98.9 \\
\hline Gibberella pulicris (tub2) & AF414866, AAN0378795.78 & $3(197,57,48 \mathrm{bp})$ & 97.4 \\
\hline Gibberella fujikuroi & U27303, AAB18275 95.78 & $4(179,59,48,49 \mathrm{bp})$ & 99.2 \\
\hline Colletotrichum gloeosporioides & U14138, AAA62875 96.96 & $6(184,58,71,56,71,53 \mathrm{bp})$ & 95.3 \\
\hline Botryotinia fukeliana & Z69263, CAA9325497.66 & $6(135,53,69,56,52,56 \mathrm{bp})$ & 95.9 \\
\hline Neurospora crassa & M13630, AAA3361795.78 & $6(240,74,68,65,73,57 \mathrm{bp})$ & 96.1 \\
\hline Rhynchosporium secalis & X81046, CAA5693696.02 & $6(132,55,77,70,52,50 \mathrm{bp})$ & 96.3 \\
\hline
\end{tabular}

Paecilomyces lilacinus ${ }^{a}$ : Paecilomyces lilacinus 36-1 strain 
Table 4 Amino acid mutation points of the $\beta$-tubulin gene of Paecilomyces lilacinus

\begin{tabular}{lllll}
\hline Strain & \multicolumn{4}{l}{ Amino acid at codon } \\
\cline { 2 - 5 } & $145^{\text {th }}$ & $185^{\text {th }}$ & $198^{\text {th }}$ & $200^{\text {th }}$ \\
\hline P36-1 & S & T & E & F \\
P50 & S & T & E & Y \\
P100 & A & A & E & $Y$ \\
\hline
\end{tabular}

$A=$ alanine; $F=$ phenylalanine; $S=$ serine $;=$ threonine; $E=$ Glutamic acid; $Y=$ tyrosine

Fungicide-resistance of transformant strains

Six transformant strains, varied in their carbendazim resistance level, were obtained from the wild strain, $P l$ 36-1. The overexpressed strains (PL1, PL2, PL4, PL5, and PL6) via p1, p2, p4, P5 or p6 vector could not grow in PDA containing $100 \mu \mathrm{g} / \mathrm{ml}$ carbendazim and $400 \mu \mathrm{g} / \mathrm{ml}$ of carboxin, while they could grow in PDA containing $50 \mu \mathrm{g} / \mathrm{ml}$ carbendazim. The transformant strain (PL3), S145A, T185A and F200Y substitutions, could normally grow in PDA containing $100 \mu \mathrm{g} / \mathrm{ml}$ carbendazim. However the substitutions of S145A and/or T185A could not succeed to induce carbendazim-resistant $(100 \mu \mathrm{g} / \mathrm{ml})$ strain, such success was achieved when both substitutions were combined with F200Y. According to the carbendazim-resistant test, PL3 was chosen to be implemented in the next biological applications and expression level quantification. Due to anticipatory cross-resistance relationship between carbendazim and diethofencarb in $P$. lilacinus, diethofencarb-resistance tests for concerned isolates of $P$. lilacinus were conducted. The results exhibited that, P. lilacinus 36-1, P50, P100, and PL3 were resistant $(70 \mu \mathrm{g} / \mathrm{ml})$ to diethofencarb. The hyphal growth and conidial germination of all tested strains were not affected by diethofencarb concentrations up to $1.0 \mu \mathrm{g} / \mathrm{ml}$ (Supplementary Fig. 2a and b). According to Sclerotinia sclerotiorum A, the transformant strain containing p3 vector (SL3) could normally grow in PDA containing $100 \mu \mathrm{g} / \mathrm{ml}$ carbendazim, while the wild strain was growing in PDA containing no more than $10 \mu \mathrm{g} / \mathrm{ml}$ carbendazim. S. sclerotiorum A was used as an example to confirm the feasibility

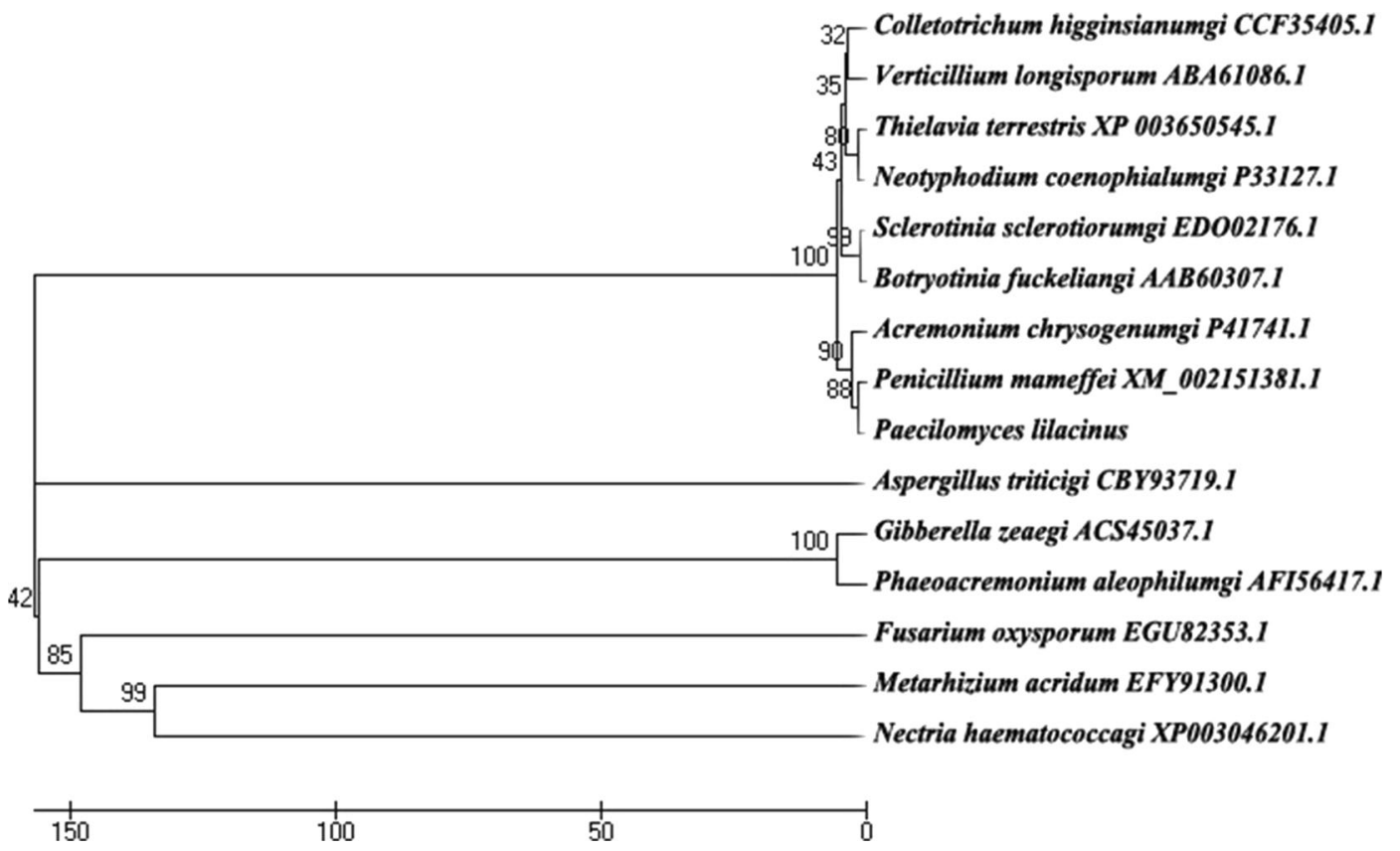

Fig. 3 Phylogenetic trees showing the relationship of $P$. lilacinus 36-1 (Pl36-1) to closely related species. The tree was inferred from $\beta$-tubulin gene sequence data by the neighbor-joining method. The and 50 bases, respectively. Numbers at the nodes indicate the levels of bootstrap support calculated from 1000 trees. Species names are followed by GenBank accession numbers 
Fig. 4 Modeling of the threedimensional structures of the $\beta$ tubulin gene protein. Two diagrams were constructed with Pymol software. The exposed surface structures of $\beta$-tubulin gene I (141-145), II (181-185), and III (196-200) are marked in magenta, yellow, and red, respectively. Spheres structures of $\beta$-tubulin gene are marked in cyan

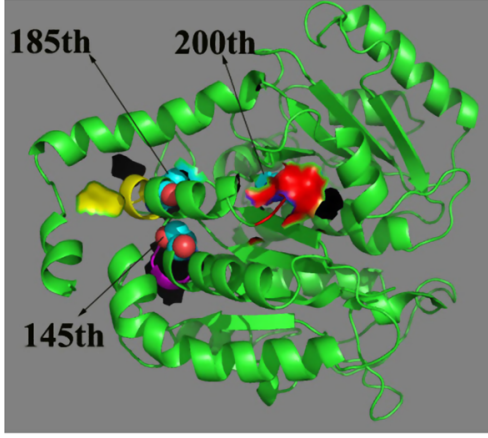

P.lilacinus 36-1

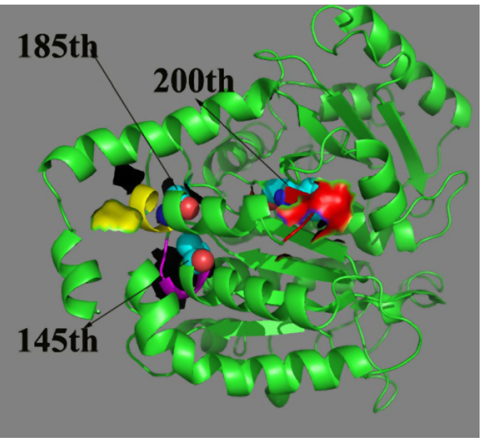

$P 100$ of inserting modified $\beta$-tubulin gene with other fungal species.

Expression level of $\beta$-tubulin

Expression levels of $\beta$-tubulin gene were quantified by qRT-PCR to analyze changes in $\beta$-tubulin expression in PL3 and SL3 relative to Pl36-1 and S. sclerotiorum A, respectively. The quantification level of $\beta$-tubulin gene expression in PL3 increased 4-fold over its normal expression level in Pl36-1. Moreover, $\beta$-tubulin expression level with SL3 increased 4.5-fold over its normal level in S. sclerotiorum A (Fig. 5).

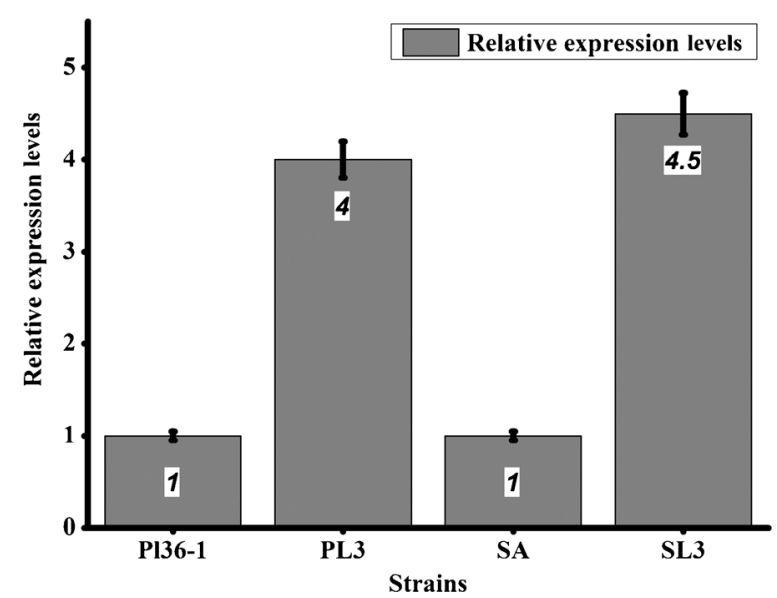

Fig. 5 qRT-PCR analysis of $\beta$-tubulin expression. Relative to the expression levels in the parent strains, PL3 increased about $400 \%$ and SL3 increased $450 \%$. PL3 and SL3 are mutants with $\beta$-tubulin gene transformation in P. lilacinus and $S$. sclerotiorum strains, respectively. The presented data express the mean $\pm \mathrm{SD}$ of three biological replicates. All comparisons with the relevant parent strain were statistically significant $(P<0.05)$
Fitness characteristics of $P$. lilacinus

Fitness of wild type, mutant and overexpressed strains of $P$. lilacinus were evaluated in vitro to examine the behavior of the transformant strains. The results revealed that the differences in fitness were not significant between all tested strains. The growth rate and sporulation of PL3, $\beta$-tubulin transformant strain with $\mathrm{p} 3 \mathrm{vec}-$ tor, recorded $0.60 \mathrm{~cm} /$ dish with conidial concentration of $3.81 \times 10^{7} \mathrm{CFU} /$ dish, while the parent strain Pl36-1 achieved growth rate of $0.59 \mathrm{~cm} /$ dish with conidial concentration of $3.84 \times 10^{7} \mathrm{CFU} /$ dish (Table. 5 and Supplementary Fig. 1). The conidia and mycelia of the PL3 strain were identical in shape and size of its parent strain Pl36-1. According to the pathogenicity against Meloidogyne incognita, the test confirmed that the transformant strain PL3 was still maintaining the pathogenicity level of its parent strain, Pl36-1 against eggs and larvae of $M$. incognita. PL3 achieved $63.6 \%$ of egg parasitism and its metabolites killed $68.2 \%$ of the nematode larvae compared to 63.5 and $68.4 \%$ with Pl36-1, respectively (Table 5). The previous results provide evidence that the alteration of $\beta$-tubulin gene in P. lilacinus did not influence the fungal growth, reproduction and virulence against $M$. incognita.

Three-year field experiments were conducted to test the stability and effectiveness of carbendazim-resistance strains at the population level. Data in Table 6 confirmed that the P100 and PL3 strains achieved high performance and persistence in the field throughout each year. Moreover, both strains recorded yield improvement ranging between 20.5 and $24.5 \%$. No significant $(p>0.05)$ differences were detected between the fitness criteria of P100 and PL3 strains. On the contrary, statistically significant $(p<0.05)$ changes were detected between both mutants and their parent strain P. lilacinus 
Table 5 Fitness characteristics of $P$. lilacinus strains under laboratory conditions

\begin{tabular}{lllll}
\hline Strains & $\begin{array}{l}\text { Growth rate } \\
(\mathrm{cm} / \mathrm{d})\end{array}$ & $\begin{array}{l}\text { Conidiation } \\
\left(10^{7} \text { CFU/dish }\right)\end{array}$ & $\begin{array}{l}\text { Egg } \\
\text { parasitism } \\
(\%)\end{array}$ & $\begin{array}{l}\text { Larval } \\
\text { mortality } \\
(\%)\end{array}$ \\
\hline P36-1 & $0.59^{\mathrm{a}} \pm 0.1$ & $3.84^{\mathrm{a}} \pm 0.2$ & $63.5^{\mathrm{a}} \pm 0.3$ & $68.4^{\mathrm{a}} \pm 0.2$ \\
PL3 & $0.60^{\mathrm{a}} \pm 0.2$ & $3.81^{\mathrm{a}} \pm 0.4$ & $63.6^{\mathrm{a}} \pm 0.1$ & $68.2^{\mathrm{a}} \pm 0.2$ \\
\hline
\end{tabular}

- The data are expressed as mean $\pm \mathrm{SD}$

- Mean values with the same letter within single column are not significantly different by Duncan's multiple range test at 0.05 level

36-1. The mutant P100 achieved the highest persistence among the tested strains recording $5.9 \times 10^{6}$ spores/ $100 \mathrm{~g}$ soil in the third year. It also exhibited the highest virulence against root-knot nematodes recording $132 \mathrm{~J}_{2} /$ $100 \mathrm{~g}$ soil and root gall index of 1.4 in the second and third year, respectively.

\section{Discussion}

To our knowledge, this is the first report demonstrating the full-length sequence and cDNA sequence of the $\beta$ tubulin gene in P. lilacinus. The $\beta$-tubulin genes of the $P$. lilacinus strains with different resistance to carbendazim were sequenced to confirm resistance mechanisms of the $\beta$-tubulin gene.

Extensive work has been conducted in the area of the $\beta$-tubulin gene resistance mechanism. The principle of benzimidazole resistance is closely associated with point mutations in the $\beta$-tubulin genes that change the structure of the fungicide-binding point (Gafur et al. 1998; Albertini et al. 1999; Peres et al. 2004; Chung et al. 2006; Davidson et al. 2006; Ziogas et al. 2009). T274I, R282Q, and Q292E mutations significantly weakened the interactions and binding of the drugs taxol and epothilone (Natarajan and Senapati 2012), while Q43P and R318W mutations had a significant impact on platelet physiology in immune thrombocytopenia (Freson et al. 2005; Kunishima et al. 2009; NavarroNunez et al. 2011). The genetics of carbendazim resistance in Aspergillus nidulans (van Tuyl 1977), Ustilago maydis (Ziogas and Girgis 1993) and other fungal species revealed that in most cases it was based on a single gene. The well-characterized amino acid substitutions E198A, E198V, E198K and F200Y were found to be responsible for this target-site insensitivity in carbendazim-resistant $B$. cinerea isolates (Yarden and Katan 1993; Leroux et al. 2002). The codon 198 of the $\beta$-tubulin gene in carbendazim-resistant Neurospora crassa is glutamic acid and codon 200 is phenylalanine (Fujimura et al. 1992). Mutation in position F167Y was observed in ruminant gastrointestinal nematodes such as Haemonchus contortus and Trichostrongylus colubriformis (Prichard 2001; Silvestre and Cabaret 2002), while some other resistant nematodes have a tyrosine residue instead of phenylalanine at position 200 of $\beta$-tubulin (Elard and Humbert 1999; Winterrowd et al. 2003). In the present study, the high-resistance mutants P50 and P100 also have a tyrosine residue instead of phenylalanine at position 200 of $\beta$-tubulin (Table 4). Moreover, the P100 mutant has two more points, S145A and T185A, of mutation leading to more

Table 6 Fitness characteristics of $P$. lilacinus strains under field condition

\begin{tabular}{|c|c|c|c|c|c|c|c|c|c|c|c|c|}
\hline \multirow[t]{2}{*}{ Treament } & \multicolumn{4}{|c|}{ December 2012 to February 2013} & \multicolumn{4}{|c|}{ November 2013 to January 2014} & \multicolumn{4}{|c|}{ March 2014 to June 2014} \\
\hline & $\begin{array}{l}\text { Spores / } \\
100 \mathrm{~g} \text { soil }\end{array}$ & $\begin{array}{l}\mathrm{J}_{2} / \\
100 \mathrm{~g} \text { soli }\end{array}$ & RGI & $\begin{array}{l}\% \text { yield } \\
\text { increase }\end{array}$ & $\begin{array}{l}\text { Spores / } \\
100 \mathrm{~g} \text { soil }\end{array}$ & $\begin{array}{l}\mathrm{J}_{2} / \\
100 \mathrm{~g} \text { soli }\end{array}$ & RGI & $\begin{array}{l}\% \text { yield } \\
\text { increase }\end{array}$ & $\begin{array}{l}\text { Spores / } \\
100 \mathrm{~g} \text { soil }\end{array}$ & $\begin{array}{l}\mathrm{J}_{2} / \\
100 \mathrm{~g} \text { soli }\end{array}$ & RGI & $\begin{array}{l}\% \text { yield } \\
\text { increase }\end{array}$ \\
\hline $\mathrm{CK}^{-}$ & - & $664^{\mathrm{c}}$ & 5 & - & - & $678^{\mathrm{c}}$ & 5 & - & - & $588^{\mathrm{c}}$ & 5 & - \\
\hline CK & - & $233^{\mathrm{b}}$ & 2.56 & $10.2^{\mathrm{b}}$ & - & $221^{\mathrm{b}}$ & 2.54 & $10.2^{\mathrm{b}}$ & - & $232^{\mathrm{b}}$ & 2.75 & $8.6^{\mathrm{b}}$ \\
\hline P36-1 & 0 & $235^{\mathrm{b}}$ & 2.55 & $10.2^{\mathrm{b}}$ & 0 & $217^{\mathrm{b}}$ & 2.51 & $10.5^{\mathrm{b}}$ & 0 & $212^{\mathrm{b}}$ & 2.5 & $9.5^{\mathrm{b}}$ \\
\hline P100 & $4.9 \times 10^{6 a}$ & $156^{\mathrm{a}}$ & 1.66 & $20.5^{\mathrm{a}}$ & $5.3 \times 10^{6 \mathrm{a}}$ & $132^{\mathrm{a}}$ & 1.51 & $24.1^{\mathrm{a}}$ & $5.9 \times 10^{6 a}$ & $139^{\mathrm{a}}$ & 1.4 & $24.5^{\mathrm{a}}$ \\
\hline PL3 & $5.1 \times 10^{6 \mathrm{a}}$ & $150^{\mathrm{a}}$ & 1.57 & $20.5^{\mathrm{a}}$ & $5.3 \times 10^{6 \mathrm{a}}$ & $135^{\mathrm{a}}$ & 1.55 & $22.3^{\mathrm{a}}$ & $5.4 \times 10^{6 \mathrm{a}}$ & $145^{\mathrm{a}}$ & 1.45 & $23.3^{\mathrm{a}}$ \\
\hline
\end{tabular}

- Mean values with the same letter within single column are not significantly different by Duncan's multiple range test at 0.05 level - $\mathrm{J}_{2} / 100 \mathrm{~g}$ soil: second stage juveniles of nematodes $/ 100 \mathrm{~g}$ of soil

- RGI (Root gall index): based on the mean percentage of the root system ( 20 plants) with galls where $0=$ no galling; $1=$ trace infection with a few small galls; $2=\leq 25 \%$ roots galled; $3=26$ to $50 \% ; 4=51$ to $75 \%$; and $5=>75 \%$ roots galled 
carbendazim-resistance level compared to P50. The amino acid substitutions are in well-correspondence with Acremonium, P41741.1; Sclerotinia, XP_001594844.1 and Verticillium, ABA61128.1 (Fig. 2). This gene alteration might be responsible for inhibiting the carbendazim binding ability to the target protein and consequently induce carbendazimresistance.

The 3D homology model of $\beta$-tubulin developed in previous studies revealed that the mutation codons resulted in carbendazim-resistance of plant-pathogenic fungi include 6, 50, 134, 165, 167, 198, 200 and 257 (Robinson et al. 2004). Since S145A and T185A changes of P. lilacinus tubulin have never been demonstrated in literature as causing carbendazim resistance, their roles in this process were investigated. Our results confirmed that, neither S145A nor T185A (separately or jointly) induced resistance to carbendazim unless both were combined with F200Y substitution. Despite S145A and T185A substitutions did not induce resistance themselves; their conjugation with F200Y (P100) has doubled the carbendazim-resistance of $P$. lilacinus compared to the single substitution of F200Y (P50). The surface structure of P100 mutant may clarify this double-resistance since it was different from the wild strain Pl36-1 due to the amino acid substitution at these three sites. These surface structural changes might be a reason for producing more stable structure of $\beta$-tubulin gene leading to increased carbendazim resistance (Fig. 4).

In some fungi (e.g., Botrytis cinerea), most of carbendazim resistant strains with the change of E198A in the gene encoding $\beta$-tubulin are simultaneously very susceptible to diethofencarb such as phenotype Ben $\mathrm{R}_{1}$ (Leroux et al. 1999). The discovery of this negative cross-resistance led to the application of a mixture of carbendazim and diethofencarb which gave rise to the change of F200Y simultaneously resistant to diethofencarb "phenotype Ben $\mathrm{R}_{2}$ " (Leroux et al. 1999; Petit et al 2010). While the carbendazim-resistant mutations of F200Y in P. lilacinus tubulin were first reported in this study, it was substantial to determine diethofencarb resistance according to this change, especially that this fungicide may be used in greenhouses on vegetable crops. Preliminary studies revealed that $P$. lilacinus 36-1, P50, P100, and PL3 were resistant $(70 \mu \mathrm{g} / \mathrm{ml})$ to diethofencarb. The hyphal growth and conidial germination of all tested strains were not affected by diethofencarb concentrations up to $1.0 \mu \mathrm{g} / \mathrm{ml}$ (Supplementary Fig. $2 \mathrm{a}$ and $\mathrm{b}$ ). These findings were substantially in-line with Hwang et al (2009). Hwang's results showed a tyrosine instead of phenylalanine at the amino acid position 200 of the C. gloeosporioides tubulin producing resistance to carbendazim and "carbendazim+diethofencarb".

Regarding to resistance cost of $\beta$-tubulin transformant strains, deletion of $\beta_{2} t u b$ in $G$. zeae reduced conidiation, vegetative growth and pathogenicity decelerated growth and reduced hyphal branching (Qiu et al. 2012). Contrary to expectation that $\beta$-tubulin gene alteration may affects fungal fitness, our in vitro studies confirmed that the PL3 and SL3 mutants could grow normally in PDA containing $100 \mu \mathrm{g} / \mathrm{mL}$ carbendazim. Moreover, no significant differences were observed between the wild strain (Pl36-1) and the overexpressed strain (PL3) in linear mycelia growth, spore production and pathogenicity.

The present research gives an insight on improving the carbendazim-resistance of the nematophagous fungus, $P$. lilacinus. New amino acid substitution sites in $\beta$ tubulin gene have been analyzed for effective carbendazim-resistance. Amino acid substitutions caused by site-direct changes at particular target codons $(145,185$ and 200) were manifested to be the cause of fungicide resistance by loss or reduction of the binding affinity to benzimidazole associated with the amino acid changes in $\beta$-tubulin. Our findings, either in laboratory or field experiments, have led to three broad conclusions regarding $\beta$-tubulin gene alteration in the wild type, P. lilacinus 36-1. First, multi-mutation sites in the same gene can confer resistance. Second, the change F200Y combined with S145A and T185A induces a carbendazim-resistant mutant maintaining nematode pathogenicity. Third, the reduction of the nematodes measures combined with yield improvement introduces reliable evidence that P100 and PL3 can be considered as stable and successful strains in controlling root-knot nematodes in the field under carbendazim application programs.

Acknowledgments This study was carried out at the Key Laboratory of Plant Pathology of Hubei Province at Huazhong Agricultural University in Wuhan. This project was supported by the Special Fund for Agro-scientific Research in the Public Interest, grant numbers 201103018 and the Major State Basic Research Development Program (973) 2013CB127504. 
Conflict of interests The authors have declared that no conflict of interest exists.

\section{References}

Abdelnabby, H. M., Mohamed, H. A., \& Aly, H. E. A. (2011). Nematode-antagonistic compounds from certain bacterial species. Egyptian Journal of Biological Pest Control, 21, 209-217.

Albertini, C., Gredt, M., \& Leroux, P. (1999). Mutations of the $\beta$ tubulin gene associated with different phenotypes of benzimidazole resistance in the cereal eyespot fungi Tapeia yallundae and Tapesia acuformis. Pesticide Biochemistry and Physiology, 64, 17-31.

Anastasiadis, I. A., Giannakou, I. O., Prophetou-Athanasiadou, D. A., \& Gowen, S. R. (2008). The combined effect of the application of a biocontrol agent Paecilomyces lilacinus, with various practices for the control of root-knot nematodes. Crop Protection, 27, 352-361.

Banno, S., Fukumori, F., Ichiishi, A., Okada, K., Uekusa, H., \& Kimura, M. (2008). Genotyping of benzimidazole-resistant and dicarboximide-resistant mutations in Botrytis cinerea using real-time polymerase chain reaction assays. Phytopathology, 98, 397-404.

Bertrand, B., Nunez, C., \& Sarah, J. L. (2000). Disease complex in coffee involving Meloidogyne arabicida and Fusarium oxysporum. Plant Pathology, 49, 383-388.

Brent, K.J., \& Hollomon, D.W. (1998). Fungicide resistance: the assessment of risk. FRAC Monograph, No 2, pp 1-48.

Brent, K. J., \& Hollomon, D. W. (2007). Fungicide resistance in crop pathogens: How can it be managed? FRAC, Monograph No. 1. Brussels: Fungicide Resistance Action Committee.

Cheng, V. C., Chan, J. F., Ngan, A. H., To, K. K., Leung, S. Y., \& Tsoi, H. W. (2009). Outbreak of intestinal infection due to Rhizopus microsporus. Journal of Clinical Microbiology, 47, 2834-2843.

Chung, W. H., Ishii, H., Nishimura, K., Fukaya, M., Yano, K., \& Kajitani, Y. (2006). Fungicide sensitivity and phylogenetic relationship of anthracnose fungi isolated from various fruit crops in Japan. Plant Disease, 90, 506-512.

Cools, H. J., \& Fraaije, B. A. (2012). Resistance to azole fungicides in European populations of Mycosphaerella graminicola: Mechanisms and management, in fungicide resistance in crop protection: Risk and management (pp. 64-77). Wallingford, Oxon: CABI.

Cools, H. J., Mullins, J. G. L., Fraaije, B. A., Parker, J. E., Kelly, D. E., \& Lucas, J. A. (2011). Impact of recently emerged sterol $14 \alpha$-demethylase (CYP51) variants of Mycosphaerella graminicola on azole fungicide sensitivity. Applied and Environmental Microbiology, 77, 3830-3837.

Crow, W. T. (2013). Effects of a commercial formulation of Paecilomyces lilacinus strain 251 on overseeded bermudagrass infested with Belonolaimus longicaudatus. Journal of Nematology, 45, 223-227.

Davidse, L., \& Ishii, T. (1995). Biochemical and molecular aspects of benzimidazoles, N-phenylcarbamates and Nphenylformamidoxines and the mechanisms of resistance to these compounds in fungi. Modern selective fungicides, 305-322.

Davidson, R. M., Hanson, L. E., Franc, G. D., \& Panella, L. (2006). Analysis of $\beta$-tubulin gene fragments from benzimidazole-sensitive and -tolerant Cercospora beticola. Journal of Phytopathology, 154, 321-328.

de Almeida Engler, J., Favery, B., Engler, G., \& Abad, P. (2005). Loss of susceptibility as an alternative for nematode resistance. Current Opinion of Biotechnology, 16, 112-117 (2005). doi: 10.1016.

Dimartino, M. A., Panebianco, S., Vitale, A., Castello, I., Leonardi, C., Cirvilleri, G., \& Polizzi, G. (2011). Occurrence and pathogenicity of Pseudomonas fluorescens. and $P$. putida on tomato plants in Italy. Journal of Plant Pathology, 93, 79-87.

Elard, L., \& Humbert, J. F. (1999). Importance of the mutation of amino acid 200 of the isotype 1 beta-tubulin gene in the benzimidazole resistance of the small-ruminant parasite Teladorsagia circumcincta. Parasitology Research, 85, 452-456.

Freson, K., De Vos, R., Wittevrongel, C., Thys, C., Defoor, J., Vanhees, L., Vermylen, J., Peerlinck, K., \& Van Geet, C. (2005). The TUBB1 Q43P functional polymorphism reduces the risk of cardiovascular disease in men by modulating platelet function and structure. Blood, 106, 2356-2362.

Fujimura, M., Kanakura, T., \& Yamaguchi, I. (1992). Action mechanism of diethofencarb to a benzimidazole-resistant mutantin Neurospora crassa. Journal of Pesticide Science, 17, 237.

Gafur, A., Tanaka, C., Shimizu, K., Ouchi, S., \& Tsuda, M. (1998). Molecular analysis and characterization of the Cochliobolus heterostrophus $\beta$-tubulin gene and its possible role in conferring resistance to benomyl. Journal of General and Applied Microbiology, 44, 217-223.

Gallo, M., Ciccarese, F., \& Sasanelli, N. (2011). Control of Pyrenochaeta lycopersici and Meloidogyne incognita on tomato by eco-compatible treatments. Acta Horticulturae, 914, 341-344.

Georgopoulos, S. G., \& Skylakakis, G. (1986). Genetic variability in the fungi and the problem of fungicide resistance. Crop Protection, 5, 299-305.

Hallman, J., Davies, K. G., \& Sikora, R. (2009). Biological control using microbial pathogens, endophytes and antagonists. In R. N. Perry, M. Moens, \& J. L. Starr (Eds.), Root-knot Nematodes (pp. 380-411). Wallingford: CAB International.

Hammond, J. W., Cai, D., \& Verhey, K. J. (2008). Tubulin modifications and their cellular functions. Current Opinion in Cell Biology, 20, 71-76.

Hooper, D. J. (1984). Extraction of nematode from plant material. In J. F. Southey (Ed.), Laboratory Methods for work with Plants and Soil Nematodes (pp. 59-80). London-HMSO: Ministry of Agriculture, Fisheries and Food.

Huang, W. K., Sun, J. H., Cui, J. K., Wang, G. F., \& Kong, L. A. (2014). Efficacy Evaluation of Fungus Syncephalastrum racemosum and Nematicide Avermectin against the RootKnot Nematode Meloidogyne incognita on Cucumber. PLOS ONE, 9, e89717.

Hussey, R. S., \& Janssen, G. J. W. (2002). Root-knot nematode: Meloidogyne species. In J. L. Starr, R. Cook, \& J. Bridge (Eds.), Plant Resistance to Parasitic Nematodes (pp. 43-70). Wallingford: CAB International. 
Hwang, S., Kim, H. R., Kim, J., Park, J. H., Lee, S. B., Cheong, S. R., \& Kim, H. T. (2009). Sensitivity of Colletotrichum spp. Isolated from Grapes in Korea to Carbendazim and the Mixture of Carbendazim Plus Diethofencarb. Plant Pathology Journal, 26, 49-56.

Javed, N., Gowen, S. R., Inam-ul-haq, M., Abdollah, K., \& Shahina, F. (2006). Systemic and persistent effect of neem (Azadirachta indica) formulations against root-knot nematodes, Meloidogyne javanica and their storage life. Crop Protection, 26, 911-916.

Khan, A., Williams, K. L., \& Nevalainen, H. K. M. (2006). Control of plant-parasitic nematodes by Paecilomyces lilacinus and Monacrosporium lysipagum in pot trials. Biocontrol, 51, 643-658.

Kiewnick, S., \& Sikora, R. A. (2006). Biological control of the rootknot nematode Meloidogyne incognita by Paecilomyces lilacinus strain 251. Biological Control, 38, 179-187.

Kunishima, S., Kobayashi, R., Itoh, T. J., Hamaguchi, M., \& Saito, H. (2009). Mutation of the beta1-tubulin gene associated with congenital macrothrombocytopenia affecting microtubule assembly. Blood, 113, 458-461.

Lamovsek, J., Urek, G., \& Trdan, S. (2013). Biological control of root-Knot nematodes (Meloidogyne spp.): Microbes against the Pests. Acta Agriculturae Slovenica, 101, 263-275.

Leroux, P., Chapeland, F., Desbrosses, D., \& Gredt, M. (1999). Patterns of cross-resistance to fungicides in Botryotinia fuckeliana (Botrytis cinerea) isolates from French vineyards. Crop Protection, 18, 687-697.

Leroux, P., Fritz, R., Debieu, D., Albertini, C., Lanen, C., \& Bach, J. (2002). Mechanisms of resistance to fungicides in field strains of Botrytis cinerea. Pest Management Science, 58, 876-888.

Luck, J. E., \& Gillings, M. R. (1995). Rapid identification of benomyl resistant strains of Botrytis cinerea using the polymerase chain reaction. Mycological Research, 99, 1483-1488.

Ma, Z., \& Michailides, T. J. (2005). Advances in understanding molecular mechanisms of fungicide resistance and molecular detection of resistant genotypes in phytopathogenic fungi. Crop Protection, 24, 853-863.

Natarajan, K., \& Senapati, S. (2012). Understanding the Basis of Drug Resistance of the Mutants of ab-Tubulin Dimer via Molecular Dynamics Simulations. PLoS ONE, 7(8), e42351.

Navarro-Nunez, L., Teruel, R., Anton, A. I., Nurden, P., MartinezMartinez, I., Lozano, M. L., Rivera, J., Corral, J., Mezzano, D., Vicente, V., \& Martinez, C. (2011). Rare homozygous status of P43 beta1-tubulin polymorphism causes alterations in platelet ultrastructure. Thrombosis and Haemostasis, 105, 855-863.

Peres, N. R., Souza, N. L., Peever, T. L., \& Timmer, L. W. (2004). Benomyl sensitivity of isolates of Colletotrichum acutatum and C. gloeosporioides from citrus. Plant Disease, 88, 125130.

Petit, A. N., Vaillant-Gaveau, N., Walker, A. F., Leroux, P., Baillieul, F., Panom, M. L., Clément, C., \& Fontaine, F. (2010). Determinants of fenhexamid effectiveness against grey mould on grapevine: Respective role of spray timing, fungicide resistance and plant defences. Crop Protection, 29, $1162-1167$.

Prichard, P. K. (2001). Genetic variability following selection of Haemonchus contortus with anthelmintics. Trends Parasitology, 17, 445-453.
Qiu, J. B., Huang, T. T., Xu, J. Q., Bi, C. W., Chen, C. J., \& Zhoua, M. G. (2012). $\beta$-Tubulins in Gibberella zeae: their characterization and contribution to carbendazim resistance. Pest Management Science, 68, 1191-1198.

Robinson, M. W., McFerran, N., Trudgett, A., Hoey, L., \& Fairweather, I. (2004). A possible model of benzimidazole binding to $\beta$-tubulin disclosed by invoking an inter-domain movement. Journal of Molecular Graphics and Modelling, 23, 275-284.

Sikora, R. A., \& Fernandez, E. (2005). Nematode parasites of vegetables (pp. 319-392). Wallingford: CABI Publishing.

Silvestre, A., \& Cabaret, J. (2002). Mutation in position 167 of isotype $1 \beta$-tubulin gene of Trichostrongyllid nematodes: role in bezimidazole resistance? Molecular and Biochemical Parasitology, 120, 297-300.

Starr, J. L., Jeger, J., Martin, R. D., \& Schilling, K. (1989). Effects of Meloidogyne incognita and Fusarium oxysporum $f$. sp. vasinfectum on plant mortality and yield of cotton. Phytopathology, 79, 640-646.

Tanaka, C., Kubo, Y., \& Suda, M. T. (1988). Comparison of mutagens in Cochliobo heterostrophus mutagenesis. Annal Phytopathology Society, 54, 503-509.

van Tuyl, J. M. (1977). Genetics of fungal resistance to systemic fungicides. Doctoral thesis, Agricultural University, Wageningen, Netherlands, $137 \mathrm{pp}$.

Verhey, K. J., \& Gaetig, J. (2007). The tubulin code. Cell Cycle, 6, 2152-2160.

Vitale, A., Castello, I., Cascone, G., D'Emilio, A., Mazzarella, R., \& Polizzi, G. (2011). Reduction of corky root infections on greenhouse tomato crops by soil solarization in south Italy. Plant Disease, 95, 195-201.

Vitale, A., Rocco, M., Arena, S., Giuffrida, F., Cassaniti, C., Scaloni, A., Lomaglio, T., Guarnaccia, V., Polizzi, G., Marra, M., \& Leonardi, C. (2014). Tomato susceptibility to Fusarium crown and root rot: Effect of grafting combination and proteomic analysis of tolerance expression in the rootstock. Plant Physiology and Biochemistry, 83, 207-216.

Wilson, M.J., \& Jackson, T.A. (2013). Progress in the commercialization of bionematicides. BioControl. doi:10, 10077.

Winterrowd, C. A., Pomroy, W. E., Sangster, N. C., Johnson, S. S., $\&$ Geary, T. G. (2003). Benzimidazole- resistant $\beta$-tubulin alleles in a population of parasitic nematodes (Cooperia oncophora) of cattle. Veterinary Parasitology, 117, 161-172.

Yang, J. K., Zhao, X. N., Liang, L. M., Xia, Z. Y., Lei, L. P., Niu, X. M., Zou, C. G., \& Zhang, K. Q. (2011). Overexpression of a cuticle-degrading protease Ver 112 increases the nematicidal activity of Paecilomyces lilacinus. Applied Microbiology and Biotechnology, 89, 1895-1903.

Yarden, O., \& Katan, T. (1993). Mutations leading to substitutions at amino acid 198 and 200 of beta-tubulin that correlate with benomyl-resistant phenotypes of field strains of Botrytis cinerea. Phytopathology, 83, 1478-1483.

Ziogas, B. N., \& Girgis, S. M. (1993). Cross-resistance relationships between benzimidazole fungicides and diethofencarb in Botrytis cinerea and their genetical basis in Ustilago maydis. Pesticide Science, 39, 199-205.

Ziogas, B. N., Nikou, D., Markoglou, A. N., Malandrakis, A. A., \& Vontas, J. (2009). Identification of a novel point mutation in the $\beta$-tubulin gene of Botrytis cinerea and detection of benzimidazole resistance by a diagnostic PCR-RFLP assay. European Journal of Plant Pathology, 125, 97-107. 